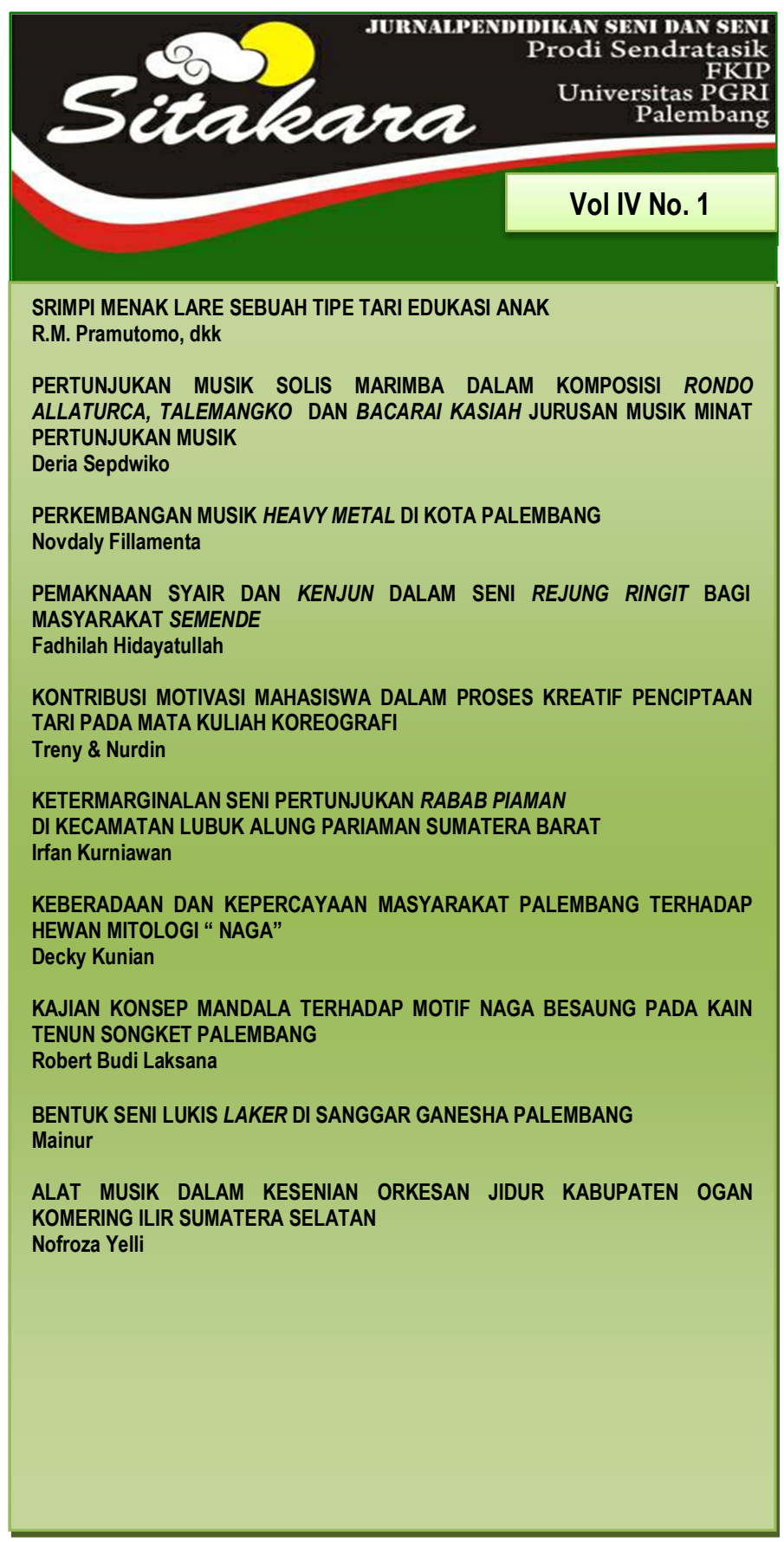




\section{DEWAN REDAKSI JURNAL "SITAKARA"}

$\begin{array}{ll}\text { 1. Penanggung Jawab } & \text { : Dra. Andina Sari, M.M } \\ \text { 2. Ketua Dewan Redaksi } & \text { : Rully Rochayati, M.Sn } \\ \text { 3. Wakil Dewan Redaksi } & \text { : Nofroza Yeli, M.Sn } \\ \text { 4. Sekretaris } & \text { : Treny Hera, S.Pd., M.Sn } \\ \text { 5. Penyunting Pelaksana } & : \text { 1. Evita Elfandari, M.Sn } \\ & \text { 2. Auzi Madona Adoma, M.Sn } \\ & \text { 3. Sherly Marita Utami, M.Pd } \\ \text { 6. Penyunting Ahli } & \text { 1. Yayan Hariyansyah, M.Sn (UIGM) } \\ & \text { 2. Desi Wardiyah, M.Pd (UPGRI) } \\ & \text { 3. Dr. Slamet, M.Hum (ISI Surakarta) } \\ & \text { 4. Hajizar, M.Sn (ISI Padang Panjang) } \\ \text { 7. Setting } & \text { 1. Drs. Marah Adiel, M.Sn } \\ & \text { 2. Mainur, S.Pd., M.Sn } \\ & \text { 3. Arfani, S.Sn., M.Pd }\end{array}$




\section{Ketentuan Penulisan Artikel Jurnal $\mathbf{S T}$ IAKA RA}

1. Naskah berbahasa Indonesia bertemakan Seni Budaya yang meliputi hasil penelitian pengajaran seni budaya, cabang seni, dan kebudayaan.

2. Naskah harus asli dan belum pernah dimuat dalam media lain. Naskah dapat berupa hasil penelitian perorangan atau kelompok.

3. Naskah ditulis dengan cara-cara yang sesuai dengan ketentuan penulisan artikel ilmiah menggunakan bahasa Indonesia yang baku, berupa ketikan, beserta soft line dalam CD-RW atau dengan mengirimkan email pada redaksi Jurnal SITAKA RA dengan alamat email: jurnalsitakarasendratasik@yahoo.com, spasi 1,5 jenis huruf Arrial Narrow ukuran 12, dengan panjang naskah antara 8-15 halaman pada kertas A4.

4. Artikel hasil penelitian memuat:

JUDUL

Nama Penulis

Abstrak

\section{A. PENDAHUluan}

B. METODE PENELITIAN

C. HASIL DAN PEMBAHASAN

D. SIMPULAN

\section{: XXX (HURUF KAPITAL)}

: (disertai jabatan dan institusi)

: (Bahasa Indonesia yang memuat 100150 kata diikuti kata kunci, dengan jenis huruf Arrial Narrow dan ukuran huruf 11 spasi tunggal serta dicetak miring)

: (Memuat latar belakang masalah, tinjauan pustaka secara ringkas, masalah penelitian dan tujuan penelitian)

5. Artikel kajian konseptual memuat:

JUDUL

Nama Penulis

Abstrak

\section{: XXX (HURUF KAPITAL)}

: (disertai jabatan dan institusi)

: (Bahasa Indonesia yang memuat 100150 kata diikuti kata kunci, dengan jenis huruf Arrial Narrow dan ukuran huruf 11 serta dicetak miring)

PENDAHULUAN
: (Memuat latar belakang masalah, tinjauan pustaka secara ringkas, 
Sub Judul

Sub Judul SIMPULAN

DAFTAR PUSTAKA masalah penelitian dan tujuan

penelitian)

: Sesuai dengan kebutuhan (tanpa numbering)

: (Berisi simpulan dan saran)

: (Berisi pustaka yang dirujuk dalam uraian naskah

6. Referensi sumber dalam teks artikel ditulis dengan menggunakan side note, contoh: (Jalalluddin, 1991:79); (Taufik, 2005;350); (Hamid dan Madjid, 2011:43). Sementara penulisan daftar pustaka disusun dengan ketentuan. Nama Pengarang. Tahun Terbit. Judul (dicetak miring). Kota Terbit: Nama Penerbit. Contoh: Koentjaraningrat. 2010. Manusia dan Kebudayaan Di Indonesia. Jakarta: Djambatan.

Daftar pustaka hanya memuat pustaka/sumber yang dirujuk dalam uraian dan disusun menurut abjad, tanpa nomor urut.

7. Naskah yang dimuat akan disunting kembali oleh redaksi tanpa mengubah isinya.

8. Naskah yang ditolak (tidak bisa dimuat) akan dikirim kembali ke penulis dengan pemberitahuan tertulis dari redaksi atau alamat email.

9. Penulis yang naskahnya dimuat akan mendapatkan 1 (satu) majalah nomor yang bersangkutan.

10. Contact Person: Treny Hera (085357344704) dan Mainur (081373165553). 


\title{
ALAT MUSIK DALAM KESENIAN ORKESAN JIDUR KABUPATEN OGAN KOMERING ILIR SUMATERA SELATAN
}

\author{
Oleh: \\ Nofroza Yelli, M.Sn \\ (Dosen FKIP Program Studi Pendidikan Sendratasik Universitas PGRI Palembang) \\ Yuriska Plastika \\ (Guru Seni Budaya/Alumni Universitas PGRI Palembang)
}

\begin{abstract}
ABSTRAK
Penelitian ini bertujuan untuk mendeskripsikan alat musik dalam kesenian orkesan jidur di Kabupaten Ogan Komering llir. Objek Penelitian adalah alat musik musik Orkesan jidur, dan subjek penelitian yaitu pemain musik Orkesan Jidur. Penelitian ini menggunakan metode kualitatif. Data dalam penelitian ini dikumpulkan menggunakan teknik observasi, wawancara, dan dokumentasi. Hasil penelitian diketahui bahwa kesenian Orkesan Jidur merupakan sebuah pertunjukan musik tanjidor yang melibatkan alat musik melodis dan ritmis. Alat musik tersebut terdiri dari Bass Drum, Snare Drum, Simbal, Terompet, Saxophone, Alto Horn, Bariton, Gitar Bass, dan Keyboard. Secara keseluruhan alat musik dalam kesenian ini berfungsi sebagai pengiring lagu baik itu lagu dangdut, pop, ataupun melayu. Alat musik bass drum, senare drum, dan simbal mempunyai peran sebagai pemberi tempo sekaligus membuat suasana lebih ramai dan semarak untuk di dengar. Terompet dan saxophone menjadi pengisi melodi dan pemberi harmoni dalam permainan Orkesan Jidur. Alto horn, bariton, serta keyboard sebagai pengisi akord, kemudian gitar bass sebagai penjelas ketukan pada musik Orkesan Jidur.
\end{abstract}

Kata Kunci : Alat musik, orkesan jidur

\section{A. PENDAHULUAN}

\section{Kebudayaan Ogan Komering llir}

Kecamatan Pedamaran merupakan salah satu dari 18 kecamatan yang ada di Ogan Komering llir (OKI), Provinsi Sumatera Selatan. Pedamaran merupakan salah satu kecamatan yang memiliki potensial dengan berbagai sumber daya alam (SDA) serta budaya yang beragam yang dimilikinya seperti kubudayaan membuat tikar dengan bahan dasar purun (tumbuhan rawa) yang dibuat dengan berbagai bentuk dan kesenian musiknya seperti orkesan jidur, sehingga melengkapi keanekaragaman budaya di 
Kabupaten Ogan Komering Ilir. Hal inilah yang menjadikan pedamaran menjadi menarik dan disoroti masyarakat banyak.

\section{Musik Orkesan Jidur}

Orkesan jidur adalah sebuah pertunjukan musik tanjidor pada umumnya, yaitu terdiri dari permainan instrumen melodis dan ritmis yang dihasilkan oleh alat tiup dan perkusi, disajikan dalam bentuk musik ansambel campuran, dan adapun Alat musik yang digunakan; terompet, saxophone alto, saxophone tenor, alto horn, perkusi bass drum, simbal, dan snare drum atau tambur yang dimainkan secara bersama-sama. Namun perbedaannya ialah musik orkesan jidur tidak dipergunakan sebagai musik arak-arakan melainkan hanya berada pada satu tempat pertunjukan, selain itu musik orkesan jidur juga terdapat seorang penyanyi. Orkesan jidur adalah sebuah pertunjukan musik yang biasanya dipertunjukan pada kegiatan budaya di desa Pedamaran, salah satunya seperti acara masak-masak atau harian petangan pada acara adat pernikahan masyarakat Pedamaran.

Dalam perkembangannya, pertunjukan orkesan jidur mengalami perubahan yakni dalam penggunaan alat musik. pada awal keberadaannya alat musik yang dipergunakan untuk pertunjukan orkesan jidur memiliki kesamaan dengan musik tanjidor pada umumnya yaitu menggunakan alat musik terompet, saxophone alto, saxophone tenor, alto horn, bass drum, simbal, dan snare drum. Namun pada tahun 2013 seorang seniman tanjidor yang merupakan pimpinan dari kelompok musik tanjidor duta suara telah mengembangkan komposisi alat musik orkesan jidur dengan menambahkan alat musik keyboard dan alat musik gitar bass. Dengan menambahkan alat musik keyboard dan gitar bass maka pertunjukan musik menjadi lebih menarik dan semarak.

\section{B. METODE PENELITIAN}

Penelitian ini menggunakan metode deskriftif kualitatif dimana peneliti mengumpulkan data melalui observasi, wawancara dan dokumentasi. Seperti yang telah diuraikan oleh Bogdan dan Taylor mengenai metodologi kualitatif sebagai prosedur penelitian yang menghasilkan data deskriptif berupa kata-kata tertulis atau lisan dari 
orang-orang dan perilaku yang dapat diamati. (Bogdan dan Taylor dalam Moleong, 2016:4).

\section{PEMBAHASAN}

Kesenian orkesan jidur dimainkan oleh pemain yang berjumlah kurang lebih 11 orang, sesuai dengan jumlah alat musik yang digunakan ditambah dengan satu orang yang berperan sebagai penyanyi. Pemusik lain terdiri dari 1 orang pemain bass drum, 1 orang pemain snare drum, 2 orang pemain terompet, 1 orang pemain saxophone, 2 orang pemain alto horn, 1 orang pemain bariton, 1 orang pemain gitar bass, 1 orang pemain keyboard, dan 1 orang penyanyi. Namun jumlah pemain bisa berubah sesuai dengan berkurang atau bertambahnya alat musik yang di gunakan.
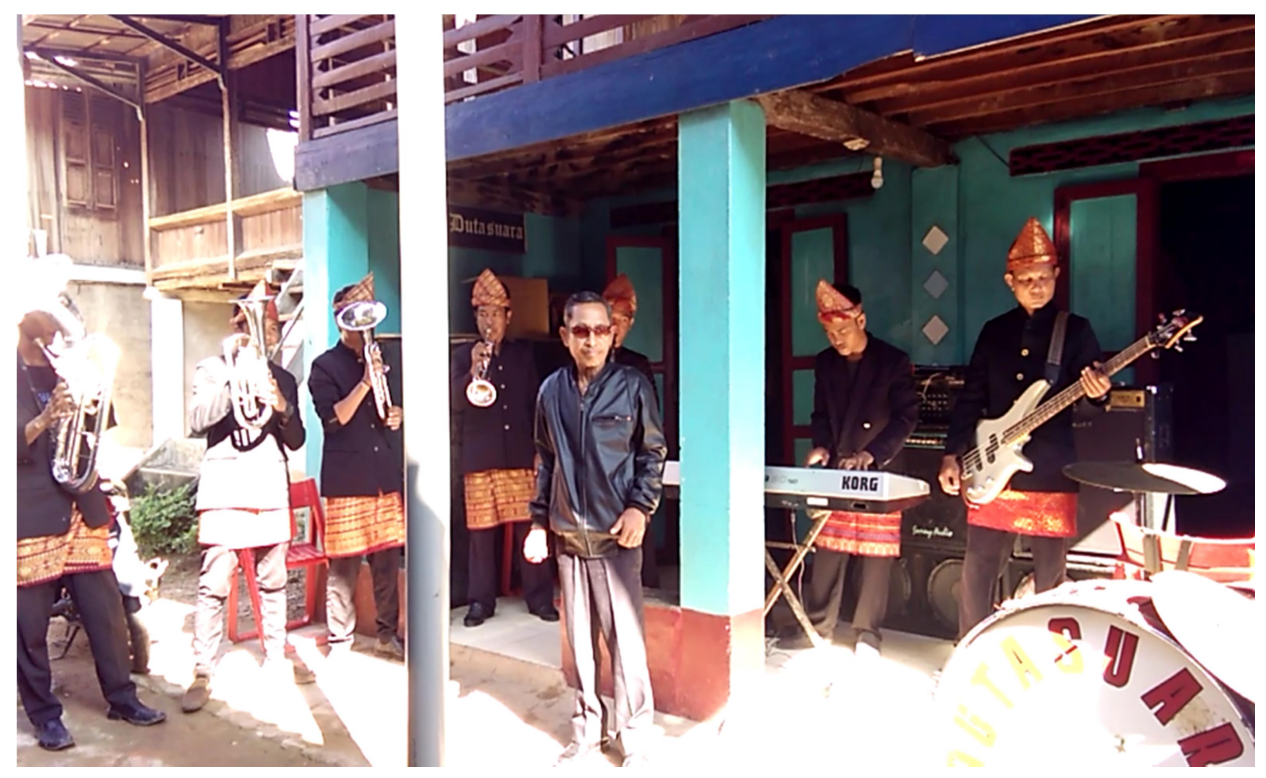

Gambar 1. Pertunjukan Orkesan Jidur, (Dokumentasi: Yuriska, 2017)

\section{Bass Drum}

Bass drum (kick drum) biasanya mempunyai diameter 18 - 26 inci. Yang paling umum digunakan adalah 22 inci. Bass drum ini memiliki satu atau dua kepala yang dimainkan dengan kaki, baik itu pedal bass tunggal maupun pedal bass doble. (Black dan Fullen, 2001:7). 
Bass drum biasanya disebut masyarakat Pedamaran dengan sebutan jidur, alat musik ini merupakan alat musik perkusi yang dimainkan dengan cara dipukul dengan menggunakan stick yang mempunyai kepala yang terbuat dari karet atau pun kain, dan bass drum diletakan pada kursi jidur yang terbuat dari kayu. (Wawancara: Hamdi Syahri, 27 Juni 2017).

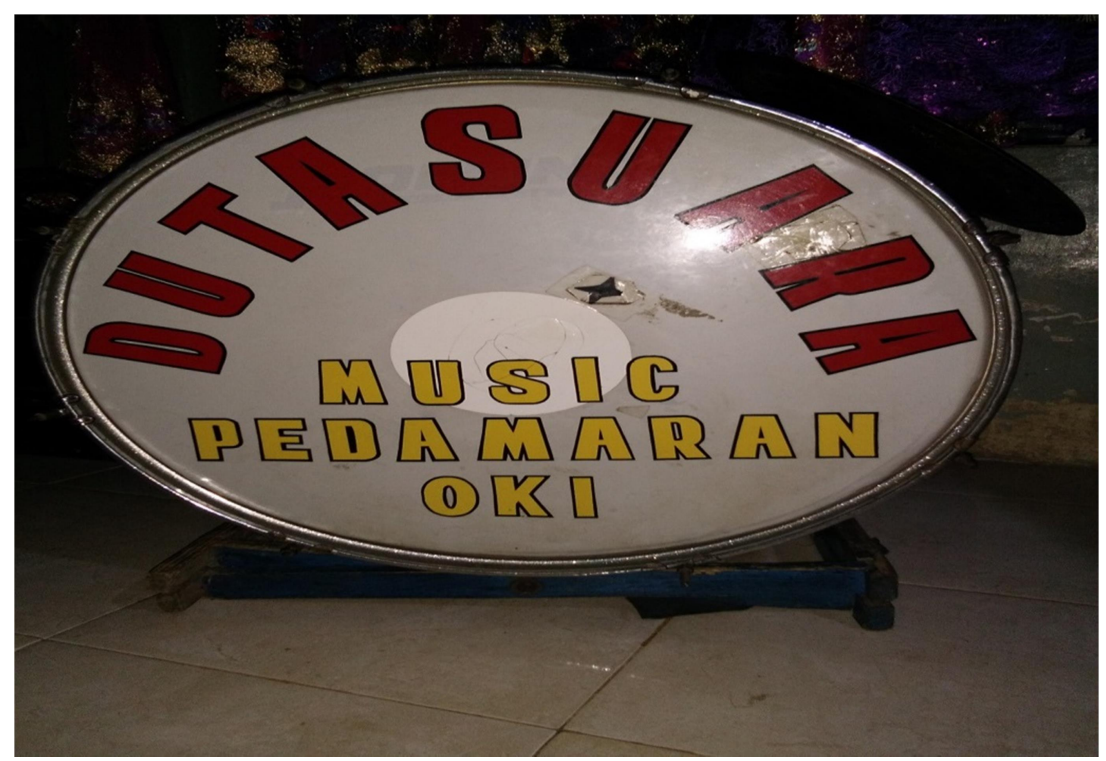

Gambar 2. Bass Drum, (Dokumentasi: Yuriska, 2017)

Teknik Memainkan: Memukul tepat pada bagian tengah membran dengan stick. Pukulan yang dilakukan pada bagian tepat ditengah membrane bertujuan untuk menghasilkan suara yang jelas. Fungsi Dalam Orkesan Jidur : Penentu ketukan dan tempo.

\section{Snare Drum}

Snare Drum adalah instrumen yang terdiri dari cangkang kayu atau logam yang dibuat berlubang, sedangkan bagian lobang masing-masing ditutupi dengan membran atau kulit sapi. Alat musik ini dimainkan dengan cara dipukul menggunakan kayu pemukul. (Goldenberg dan Cirone, 2002:73).

Snare drum oleh masyarakat Pedamaran biasanya disebut dengan istilah tambur. Tambur merupakan alat musik perkusi yang dimainkan dengan cara dipukul menggunakan dua stick yang terbuat dari kayu. (Wawancara: Herianto, 28 Juni 2017). 
Pada alat musik snare drum, terdapat tali senar yang terbuat dari baja yang direntangkan melintang pada membrane di sisi bagian bawah.
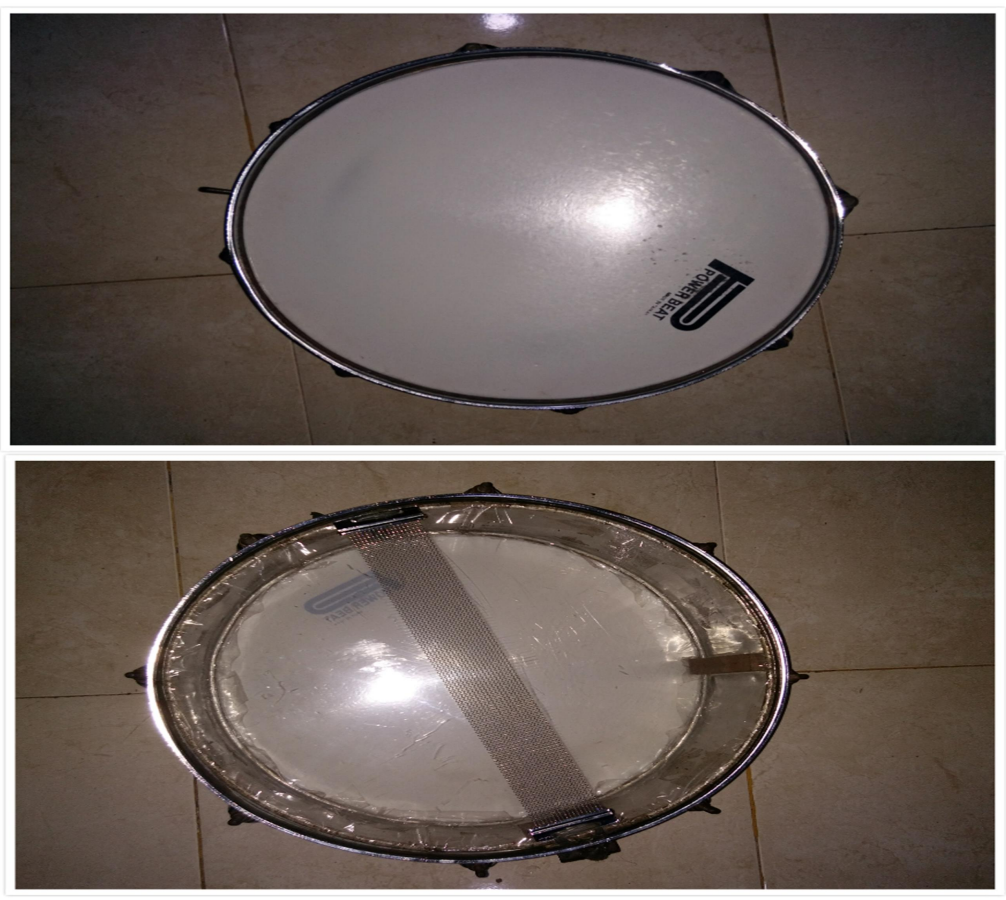

Gambar 3. Snare Drum (Tambur), (Dokumentasi: Yuriska, 2017)

Teknik Memainkan: dipukul dengan Menggunakan stick di bagian tengah membrane dengan tujuan agar meng hasilkan suara yang jelas. Fungsi Dalam Orkesan Jidur : Penentu ketukan dalam lagu yang dimainkan.

\section{Terompet}

Terompet merupakan salah satu jenis alat musik tiup yang dapat dipergunakan sebagai penyampai pesan berupa data suara. Saat ini terompet menjadi salah satu alat musik modren yang terbuat dari logam. (Nuryanto, 2012: 10).

Menurut Herianto (Wawancara, 28 Juni 2017) terompet adalah alat melodis dalam musik Orkesan Jidur yang dimainkan dengan cara ditiup. Terompet biasanya terbuat dari logam ataupun kuningan. Dalam musik orkesan jidur terompet berperan sebagai pengisi melodi dan memberikan harmoni pada muusik yang dimainkan.

Pada alat musik terompet hanya terdapat tiga tombol, yang mana tombol ini kemudian akan menghasilkan bunyi dengan nada nada yang digunakan untuk 
mengalunkan melodi pada lagu. Meskipun hanya memiliki tiga tombol namun menurut bapak Herianto pencapaian nada pada tetompet mampu mencapai 3 oktaf.

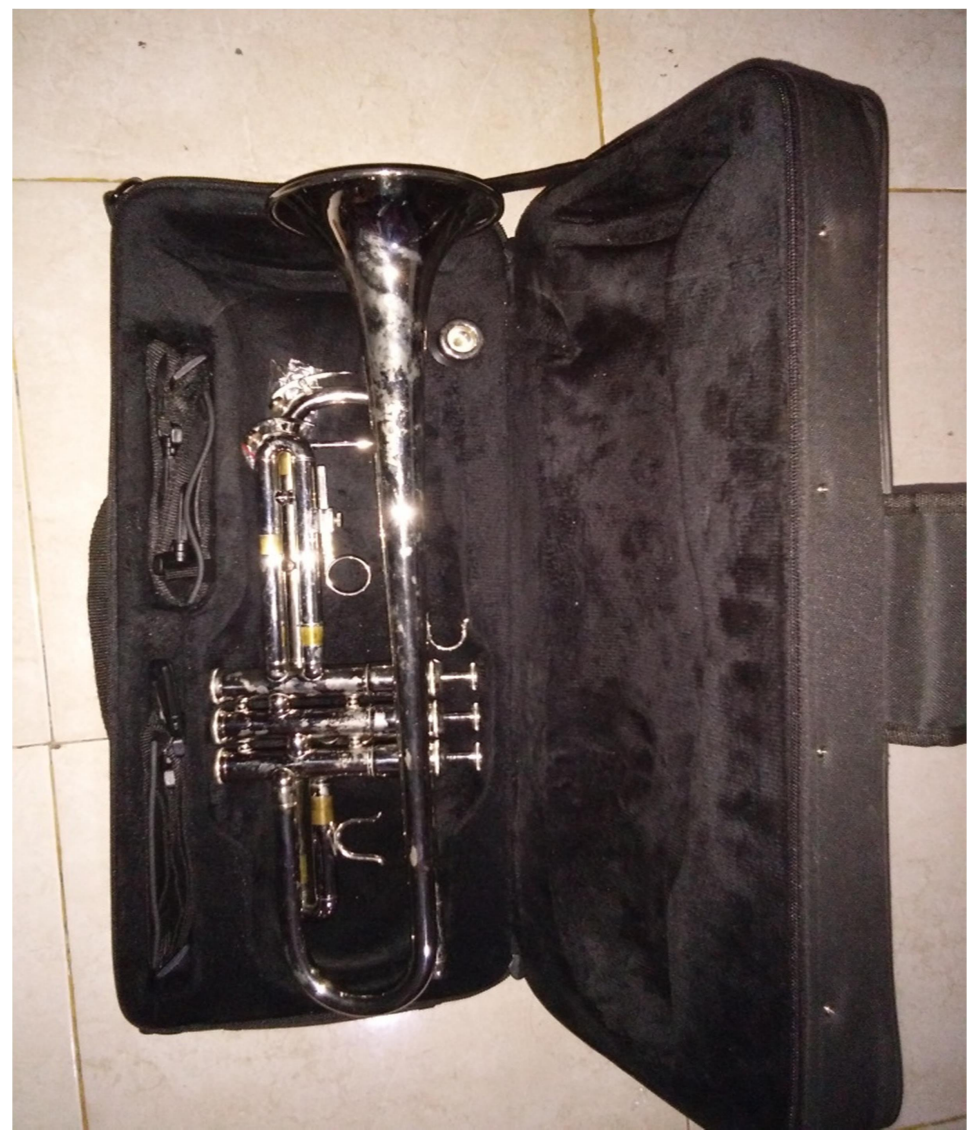

Gambar 4. Terompet, (Dokumentasi: Yuriska, 2017)

Teknik Memainkan: Ditiup, cara meniup dengan menempelkan bibir Mouthpiece dan meniup nya, serta menggetarkan bibir. Fungsi dalam Orkesan Jidur: Memainkan Melodi Lagu.

\section{Saxophone}

Saxophone merupakan alat musik tiup kayu dengan reed tunggal ciptaan Adolphe Sax, yang diperkenalkan tahun 1840. Dikategorikan sebagai woodwind (tiup kayu), sebab sumber bunyinya adalah reed (kayu). (Banoe, 2003:368).

Menurut Hamdi Syahri (Wawancara, 27 Juni 2017) saxophone adalah alat musik tiup yang terbuat dari kuningan dan merupakan alat musik melodis yang berperan dalam memainkan melodi pada lagu. 
Cara memainkan saxophone ialah dengan cara ditiup yaitu dengan menempelkan bibir pada reed atau Mouthpiece yang terdapat pada saxophone. Untuk mendapatkan bunyi yang sesuai dengan nada yang terdapat pada lagu, maka harus meniup dan menekan tombol pada saxophone.

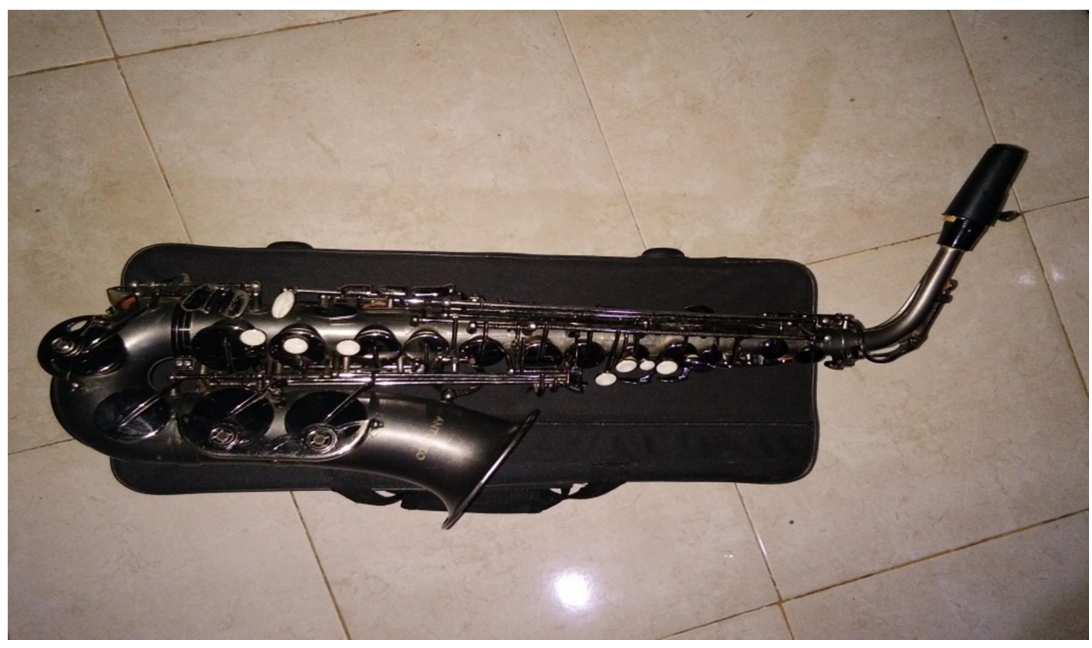

Gambar 5. Saxophone, (Dokumentasi: Yuriska, 2017)

Teknik Memainkan: Teknik tiup embouchure menggambarkan formasi antara bibir, gigi, rahang, dan otot-otot di sekitar mulut ketika udara ditiupkan melalui Mouthpiece. Secara alamiah, embouchure berakibat pada upaya untuk menghasilkan tone yang baik dan untuk mengendalikan saxophone dengan baik. Fungsi dalam Orkesan Jidur: Memainkan melodi.

\section{Alto Horn}

Alto Horn merupakan anggota keluarga dari Horn. Alat musik Horn logam merupakan tiruan dari horn tanduk binatang. Horn merupakan alat musik jenis terompet bercorong lebar berbentuk tuba (tubus). (Banoe, 2003:186).

Menurut Herianto (Wawancara, 28 Juni 2017) alto horn adalah alat musik tiup yang terbuat dari kuningan. Dalam musik Orkesan Jidur alat musik ini berperan sebagai pemberi akord pada musik.

Cara memainkan alto horn sama halnya dengan cara memainkan alat musik terompet yaitu dengan cara meletakkan bibir pada Mouthpiece yang terdapat pada alat musik tersebut. Tombol yang terdapat pada alto horn untuk menghasilkan nada juga sama 
dengan yang terdapat pada terompet, Meskipun demikian sesuai dengan perannya alto horn hanya memainkan akord saja.

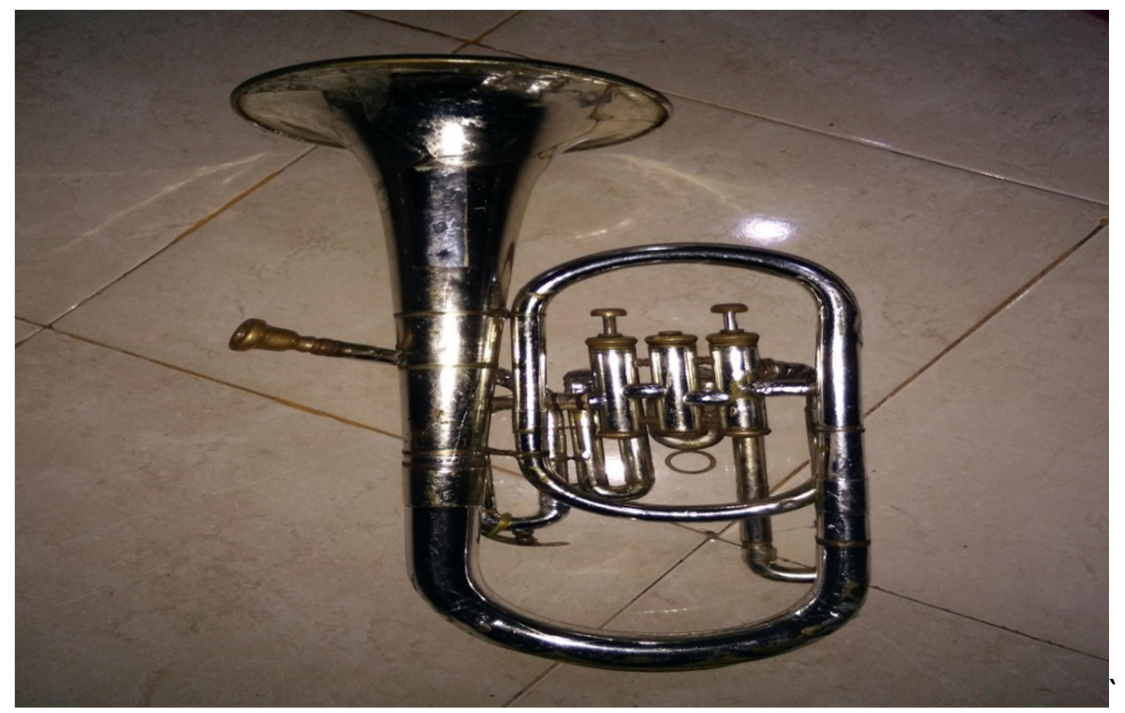

Gambar 6. Alto Horn, (Dokumentasi: Yuriska, 2017)

Teknik Memainkan: Ditiup, cara meniup dengan menempelkan bibir Mouthpiece.

Fungsi dalam Orkesan Jidur: Memainkan akord pada lagu.

\section{Bariton}

Menurut Herianto (Wawancara, 28 Juni 2017) Bariton ialah alat musik tiup yang terbuat dari kuningan. Cara memainkan alat musik bariton sama dengan cara memainkan alat musik alto horn yaitu dengan cara meniup dengan menempelkan bibir Mouthpiece dan meniup nya. Namun suara yang dihasil adalah Bass. Seperti hal nya alto horn, alat musik bariton ini juga memiliki peran dalam orkesan jidur yaitu sebagai pemberi akord pada musik yang dimainkan. 


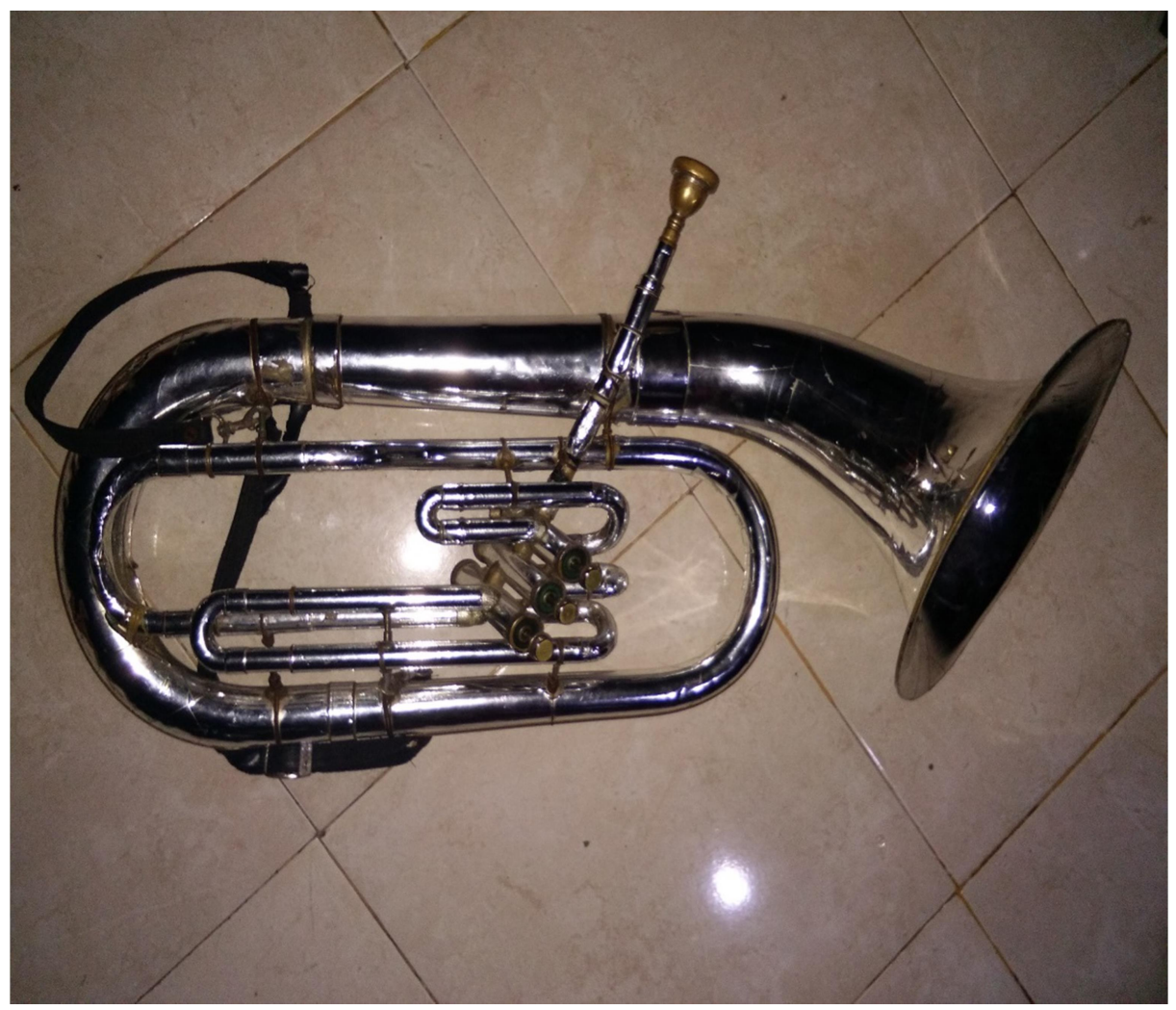

Gambar 7. Bariton, (Dokumentasi: Yuriska, 2017)

Teknik Memainkan : Ditiup, cara meniup dengan menempelkan bibir Mouthpiece dan meniup nya. Fungsi dalam Orkesan Jidur: Memainkan akord pada lagu dengan mengahsilkan suara Bass.

\section{Simbal}

Simbal merupakan pengiring logam yang bertumpu pada tongkat, dibunyikan dengan cara dipukul dengan stik pemukul. Simbal adalah bagian dari drumset. (Banoe, 2003:101).

Menurut Hamdi Syahri (Wawancara, 27 Juni 2017) simbal adalah alat musik yang terbuat dari kuningan yang dimainkan dengan cara dipukul, dalam kata lain alat musik tersebut termasuk dalam kelompok alat musik perkusi.

Dalam musik Orkesan Jidur simbal diletakkan pada badan bass drum dan juga diletakan pada stand simbal. Simbal yang berada pada badan bass drum dipukul dengan satu simbal lainnya dan simbal yang terletak pada bass drum dipukul dengan menggunakan stik. 


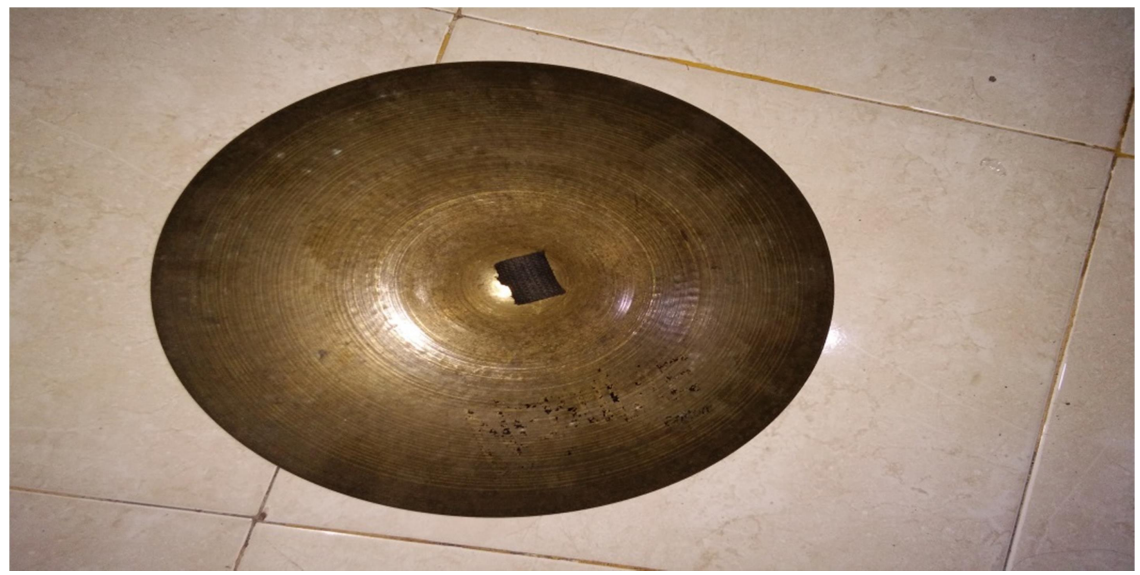

Gambar 8. Simbal, (Dokumentasi: Yuriska, 2017)

Teknik Memainkan: Dipukul, Simbal yang berada pada badan bass drum dipukul dengan satu simbal lainnya atau di adu dengan bagian simbal lainnya yang dilakukan oleh pemain bass drum, sedangkan simbal yang terletak pada stand simbal dipukul dengan menggunakan stick yang digunakan oleh pemain snare drum. Fungsi dalam Orkesan Jidur: Sebagai variasi dan pembangun suasana.

\section{Gitar Bass}

Gitar bass berfungsi sebagai bass pada alat string bass dengan penalaan yang sama (E-A-D-G). (Banoe, 2003:46).

Menurut Herianto (wawancara, 28 Juni 2017) Gitar bass adalah alat musik dawai yang menggunakan listrik. Penampilannya seperti gitar listrik lainnya tetapi ia memiliki empat senar.

Dalam musik Orkesan Jidur, gitar bass berperan untuk memperjelas ketukan pada musik yang dimainkan. Gitar bass dimainkan dengan cara dipetik, teknik petikan yang digunakan yaitu picking style. 


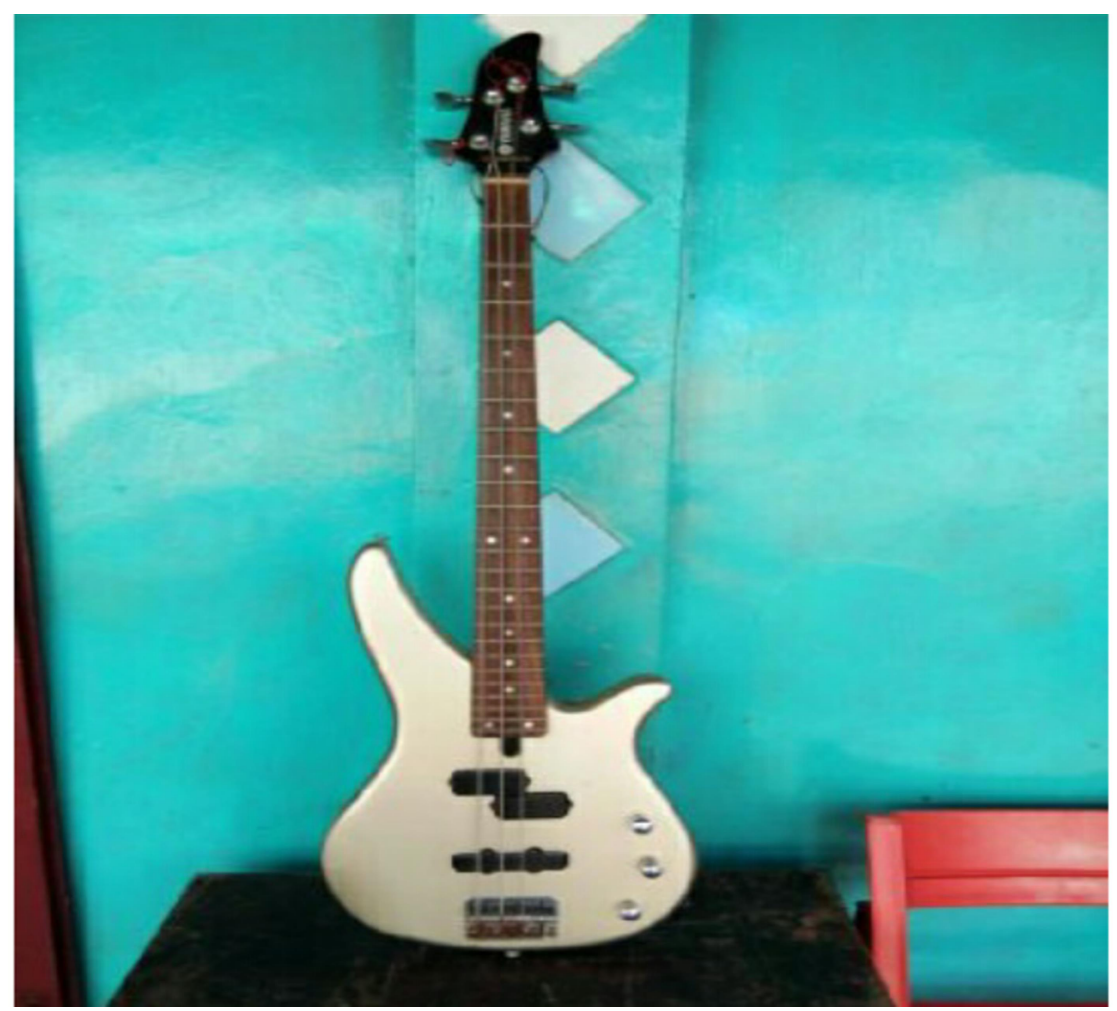

Gambar 9. Gitar Bass, (Dokumentasi: Yuriska, 2017)

Teknik Memainkan : Dipetik, teknik petikan yang digunakan yaitu teknik picking style. Fungsi dalam Orkesan Jidur : memperjelas ketukan dalam musik.

\section{Keyboard}

Keyboard adalah alat musik harmonis yang memiliki bilah-bilah papan nada. (Banoe, 2003:220). Menurut Hamdi Syahri (Wawancara, 27 Juni 2017) alat musik keyboard adalah sebuah alat musik yang yang dimainkan seperti piano, hanya saja keyboard bisa memainkan beragam suara seperti terompet, suling, gitar, biola, sampai alat musik perkusi, dan sebutan untuk alat musik keyboard oleh masyarakat pedamaran adalah orgen.

Dalam Musik Orkesan Jidur, Keyboard berfungsi untuk memberikan akord. keberadan alat musik keyboard dalam musik orkesan jidur juga menambah semarak dan musiknya terkesan ramai. 


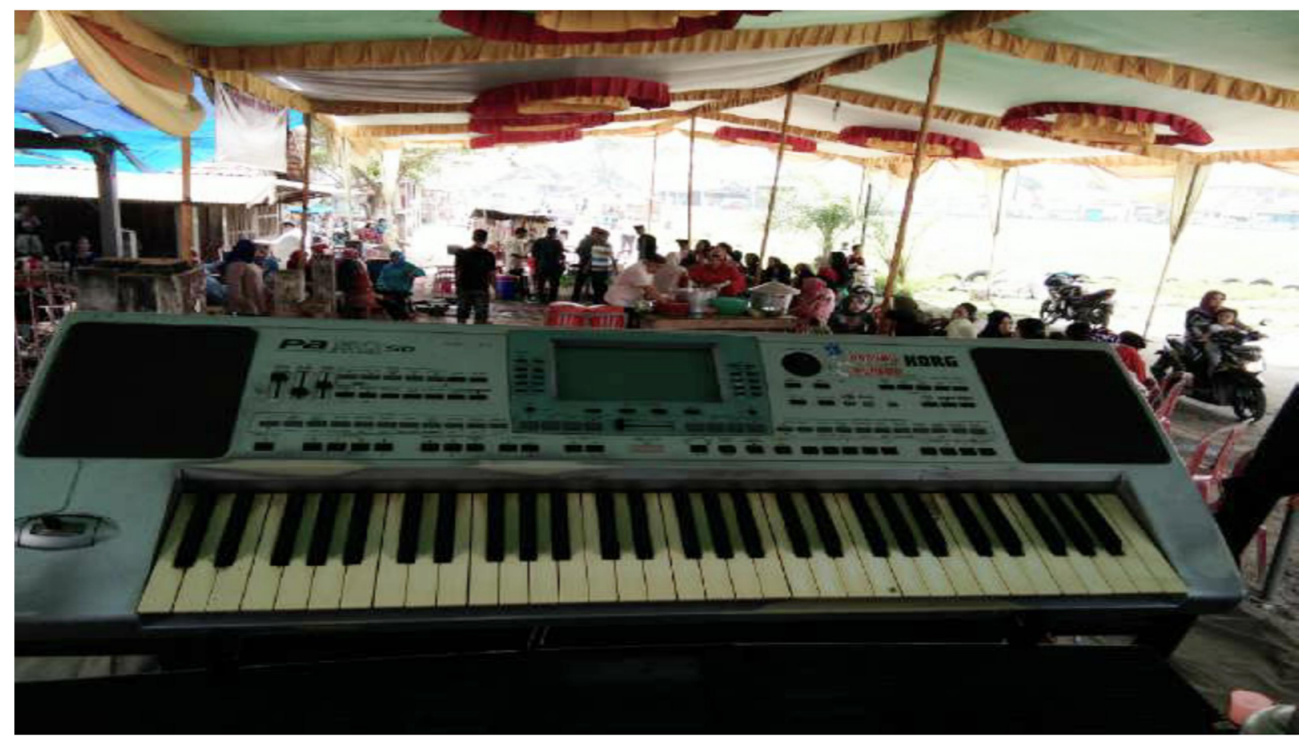

Gambar 10. Keyboard, (Dokumentasi: Yuriska, 2017)

Teknik Memainkan: Ditekan, menekan tooth (bilah-bilah nada) dengan aturan permainan akord. Fungsi dalam Orkesan Jidur: sebagai pengisi akord.

\section{SIMPULAN}

Alat musik adalah Salah satu unsur yang ada pada sebuah musik, dimana alat merupakan sebuah media penghasil bunyi dan nada-nada pada musik. Adapun alat musik yang digunakan dalam musik Orkesan Jidur semuanya dikategorikan alat musik modern. Alat musik tersebut terdiri dari terompet, saxophone, alto horn, bariton, bass drum, simbal, snare drum atau tambur, keyboard, dan gitar bass. Alat musik bass drum, senare drum, dan simbal mempunyai peran sebagai pemberi tempo sekaligus membuat suasana lebih ramai dan semarak untuk di dengar. Sedangkan terompet dan saxophone menjadi pengisi melodi dan pemberi harmoni dalam permainan Orkesan Jidur. Dan alto horn, bariton, serta keyboard sebagai pengisi akord, kemudian gitar bass sebagai penjelas ketukan pada musik Orkesan Jidur. 


\section{DAFTAR PUSTAKA}

Black, Dave. Brian Fullen. 2001. Bass Drum Essentials For The Drumset. USA: Alfred Publishing.

Banoe, Pono. 2003. Kamus Musik. Yogyakarta: Kanisius.

Goldenberg, Morris. Anthony J. Cirone. 2002. Modern School for Snare Drum. USA: Alfred Publishing.

Maleong, Lexy J. 2011. Metodologi Penelitian Kualitatif. Cet: 24. Bandung: Remaja Rosdakarya.

Nuryanto, Hery. 2012. Sejarah Perkembangan Teknologi Informasi dan Komunikasi. Jakarta: PT Balai Pustaka.

\section{NARASUMBER}

$\begin{array}{lll}\text { 1. } & \text { Nama } & \text { : Hamdi Syahri } \\ \text { Usia } & : \text { :63 Tahun } \\ & \text { Pekerjaan } & \text { : Pimpinan Tanjidor Duta Suara } \\ \text { 2. } & \text { Nama } & : \text { Herianto } \\ & \text { Usia } & : \text { 45 Tahun } \\ \text { Pekerjaan } & : \text { tokoh masyarakat pedamaran }\end{array}$

